\title{
Prediction of Vapor-Liquid Equilibria and Solid-Liquid Equilibria by the Analytical Solutions of Groups Model*
}

\author{
by Daisuke Hoshino**, Yoshiki Unno**, Kunio Nagahama** \\ and Mitsuho Hirata**
}

\begin{abstract}
Summary: The group Wilson parameters to predict liquid phase activity coeflicients by the Analytical Solutions of Groups model for the systems consisting of $\mathrm{CH}_{2}$ groups and $\mathrm{OH}$ groups were determined using isothermal vapor-liquid equilibrium data of the alcohol-water and alcoholparaffin systems in the temperaiure range $30^{\circ} \mathrm{C}$ to $90^{\circ} \mathrm{C}$. The determined group Wilson parameters were sucessfully used for prediction of isobaric vapor-liquid equilibria with pressures up to 20 atm and temperatures up to $215^{\circ} \mathrm{C}$. And, isobaric vapor-liquid equilibria were also predicted by the parameters of Tochigi and Kojima, and Derr and Deal, respectively, for comparing the predicted results with those of our work.

Also, solid-liquid equilibria were well predicted by the extended use of the Analytical Solutions of Groups model ulilizing the same parameters for predicting isobaric vapor-liquid equilibria.
\end{abstract}

\section{Introduction}

Phase equilibrium data are very important and useful for designing separation processes, for example, vapor-liquid equilibrium data for distillation and solid-liquid equilibrium data for crystallization. However only limited experimental data are available for any particular conditions of temperature, pressure and composition that are required for particular design. The "Analytical Solutions of Groups" (ASOG) model is one of the useful methods to interpolate or extrapolate the existing mixture data, or when the suitable data are not available, to estimate the desired equilibrium data.

A method for estimating liquid phase activity coefficients from group contributions was discussed and illustrated by Wilson and Deal ${ }^{31)}$ as the "Solution of Groups" model. The ASOG model discussed by Derr and Deal ${ }^{8}$, Tochigi and Kojima ${ }^{27)}$, and Ronc and Ratcliff ${ }^{25)}$ were based on the "Solution of Groups" model. By the ASOG model, liquid phase activity coefficients were predicted in terms of the parameters associated with the pairs of structual groups of the solution.

The prediction of vapor-liquid equilibria by the ASOG model has already been shown by Derr and Deal, Tochigi and Kojima, and Ronc and Ratcliff. This paper deals not only with the

* Received Jan. 18, 1977.

** Department of Industrial C'hemistry, Faculty of Engineering, 'Likyo Metropolitan University (1-1, Fukazawa, 2-chome, Setagaya-ku, Tokyo 158) prediction of vapor-liquid equilibria, but the application of the ASOG model to the prediction of solid-liquid equilibria which has not been discussed in the literature. And the assumption of Maripuri and Ratcliff ${ }^{18)}$ is used in this paper that aliphatic and aromatic carbon atoms can be treated as equivalent.

\section{The Analytical Solutions of Groups Model}

In the Analytical Solutions of Groups model, the activity coefficient of a component $i$ in solution is expressed as the sum of two contributions-one associated with the difference in molecular sizes and the other with the interaction of structural groups, as follows:

$$
\ln \gamma_{i}=\ln \gamma_{i}^{\mathrm{FH}}+\ln \gamma_{i}^{\mathrm{i}}
$$

where $\ln \gamma_{i}^{\pi}$ is the size contribution and $\ln \gamma_{i}^{\mathrm{a}}$ is associated with the interaction of the structural groups of the molecule with those of its environment.

The size term is treated in the Flory-Hugginslike manner as Eqs. (2) and (3).

$$
\begin{aligned}
& \ln \gamma_{i}^{\mathrm{FH}}=\ln \mathrm{U}_{i}+\left(1-\mathrm{U}_{i}\right) \\
& \mathrm{U}_{i}=\frac{\nu_{i}^{\mathrm{FH}}}{\sum_{j=1}^{n} \nu_{j}^{\mathrm{FB}} x_{j}}
\end{aligned}
$$

where $\nu_{i}^{\mathbb{R}}$ is the number of atoms (other than hydrogen) in molecular species $i$.

The interaction term is treated as the difference between the group contributions which arise in the solution and in the molecular standard states; these contributions are summed over all interaction groups comprising the solute molecules of interest. 
Thus:

$$
\ln r_{i}^{\mathrm{G}}=\sum_{k}^{N} \nu_{k i}\left(\ln \Gamma_{k}-\ln \Gamma_{k}^{i}\right)
$$

where $v_{k i}$ is the number of interacting groups of kind $k$ in molecule $i$. $\Gamma_{k}$ is the group activity coefficient of group $k$ and is calculated by the Wilson equation.

The form of the Wilson equation in representing group activity coefficient is given in Eq. (5). For a group, $k$, in a mixture making up $\mathrm{N}$ groups:

$$
\ln \Gamma_{\boldsymbol{k}}=-\ln \sum_{l}^{N} \mathrm{X}_{l} \mathrm{a}_{k^{\prime} l}+\left[1-\sum_{l}^{\mathrm{N}} \frac{\mathrm{X}_{l} \mathrm{a}_{l / k}}{\sum_{m}^{N} \mathrm{X}_{m} \mathrm{a}_{l / m}}\right]
$$

where $a_{k / l}, a_{l / k}$ are group Wilson parameters and $\mathrm{X}$ are group fractions. The group fraction for group $k$ is defined as the ratio of the total number of groups, $k$, from all sources to the total number of groups of all kinds in the mixture.

For a group $k$ :

$$
X_{k}=\frac{\sum_{i=1}^{n} x_{i} \nu_{k i}}{\sum_{i=1}^{n} x_{i} \sum_{\mathbf{X}}^{\mathrm{N}} \nu_{k i}}
$$

where $x$ is the mole fraction, and the sums are to be taken over all groups, $k$, and components, $i$, in the solution.

\section{Determination of Parameters in the Ana- lytical Solutions of Groups Model}

For the case of a solution containing only two groups 1 and 2, Eq. (5) becomes:

$$
\begin{aligned}
\ln \Gamma_{1}= & -\ln \left(\mathrm{X}_{1}+\mathrm{a}_{12} \mathrm{X}_{2}\right) \\
& +\mathrm{X}_{2}\left[\frac{\mathrm{a}_{12}}{\mathrm{X}_{1}+\mathrm{a}_{12} \mathrm{X}_{2}}-\frac{\mathrm{a}_{21}}{\mathrm{a}_{21} \mathrm{X}_{1}+\mathrm{X}_{2}}\right] \\
\ln \Gamma_{2}= & -\ln \left(\mathrm{a}_{21} \mathrm{X}_{1}+\mathrm{X}_{2}\right) \\
& -\mathrm{X}_{1}\left[\frac{\mathrm{a}_{12}}{\left.\mathrm{X}_{1}+\frac{\mathrm{a}_{21} \mathrm{X}_{2}}{\mathrm{a}_{12}}-\frac{\mathrm{a}_{1}+\mathrm{X}_{2}}{\mathrm{a}_{21}}\right]}\right.
\end{aligned}
$$

Using Eqs. (7) and (8), Eq. (4) is written as a function of $a_{12}$ and $a_{21}$ only at a given temperature as follows:

$$
\ln \gamma_{i}^{\sigma}=f_{i}\left(\mathrm{X}_{1}, \mathrm{a}_{12}, \mathrm{a}_{21}\right)
$$

The group Wilson parameters are determined by using isothermal vapor-liquid equilibrium data.
Defining

$$
\left.\mathrm{F}=\mid \sum_{j=1}^{m} \sum_{i=1}^{n}\left(\ln \gamma_{i, \ldots, \ldots}^{\prime:}-\ln \gamma_{i, \text { caul }}^{\prime:}\right)_{j}^{2}\right]
$$

wherc $j$ denotes the $j^{\text {th }}$ experimental point, and $F$ is a function of $a_{12}$ and $a_{21}$. Seeking the best values of $a_{12}$ and $a_{21}$ by minimizing $F$, i.e. by solving for

$$
\frac{\partial \mathrm{F}}{\partial \mathrm{a}_{12}}=\frac{\partial \mathrm{F}}{\partial \mathrm{a}_{21}}=0
$$

Direct solution of Eq. (11) appeared difficult, and a computer program was written in which the group Wilson parameters were obtained by the damped least squares fit method. The form of Eq. (5) is such that negative parameters may give rise to logalithms of negative numbers. Consequently, only positive parameters have been considered meaningful. When the parameter became negative, calculation was stopped and new calculation was made again from the initial calculation of the program using the new initial values of $a_{12}$ and $a_{21}$ to minimize $F$.

In this paper, the group Wilson parameters were obtained by isothermal vapor-liquid equilibrium data in the temperature range from $30^{\circ} \mathrm{C}$ to $90^{\circ} \mathrm{C}$ of the alcohol- water and alcohol-paraffin systems which were made up with $\mathrm{CH}_{2}$ and $\mathrm{OH}$ groups. For simplicity, no distinction is made between $\mathrm{CH}_{3}$ and $\mathrm{CH}_{2}$ groups. The equilibrium data used are shown in Table 1. The water molecule is treated as 1.6 interaction $\mathrm{OH}$ groups, and the value of $\mathrm{CH}_{2}$ group in $i$-propanol is treated as 2.8, which were the same treatments used by Tochigi and Kojima.

The group Wilson parameters determined at 30 , 50,60 and $90^{\circ} \mathbf{C}$ are listed in Table 2 and they

\begin{tabular}{|c|c|}
\hline $\begin{array}{c}\text { Temp. } \\
\left({ }^{\circ} \mathrm{C}\right)\end{array}$ & System \\
\hline 30 & n-Propanol-Water ${ }^{32)}$, Ethanol-n-Hexane ${ }^{13)}$ \\
\hline 50 & Methanol-Water ${ }^{19)}$, Ethanol-Water'), Ethanol-n-Heptane ${ }^{26)}$ \\
\hline 60 & Methanol-Water ${ }^{5)}$, Ethanol-Water ${ }^{28)}, n$-Propanol-Water ${ }^{20)}, i$-Propanol-n-Heptane ${ }^{29)}$ \\
\hline 90 & $n$-Propanol-Water ${ }^{24)}, n$-Propanol-n-Decane ${ }^{24)}$ \\
\hline
\end{tabular}
were satisfactorily correlated with a function of absolute temperature as follows:

$$
\begin{aligned}
& a_{\mathrm{CH}_{2} / \mathrm{OH}}=\exp \left(-0.9323-\frac{105.9}{\mathrm{~T}}\right) \\
& \mathrm{a}_{\mathrm{OH} / \mathrm{CH}_{2}}=\exp \left(1.1373-\frac{1684.8}{\mathrm{~T}}\right)
\end{aligned}
$$

Eqs. (12) and (13) were successfully used even within the temperature range from $90^{\circ} \mathrm{C}$ to $215^{\circ} \mathrm{C}$.

Table 1 Isothermal Vapor-Liquid Equilibrium Data Used for the Determination of the Group Wilson Parameters 
that will be shown later in the part of the prediction of the isobaric vapor-liquid equilibria.

Table 2 Determined Group Wilson Parameters

\begin{tabular}{c|c|c|c}
\hline $\begin{array}{c}\text { Temp. } \\
\left({ }^{\circ} \mathrm{C}\right)\end{array}$ & $\mathrm{a}_{\mathrm{CH}_{2} / \mathrm{OH}}$ & $\mathrm{a}_{\mathrm{OH} / \mathrm{CH}_{2}}$ & R.M.S.D. \\
\hline 30 & 0.2648 & 0.0123 & 0.0914 \\
50 & 0.3005 & 0.0169 & 0.0890 \\
60 & 0.2935 & 0.0190 & 0.1121 \\
90 & 0.2840 & 0.0309 & 0.0491 \\
\hline \multicolumn{2}{l}{ R.M.S.D. $=\sqrt{\left.\left[\sum_{j=1}^{m} \sum_{i=1}^{n}\left(\ln \gamma_{i, c \times p}^{0}-\ln \gamma_{i, c a l}^{0}\right)_{j}\right]\right] / m}$}
\end{tabular}

\section{Prediction of Vapor-Liquid Equilibria}

The liquid phase activity coefficients for the component $i$ of vapor-liquid equilibria were calculated from the following relationship,

$$
\gamma_{i}=\frac{y_{i} \pi}{x_{i} \mathbf{P}_{i}^{\circ}}
$$

Eq. (14) can be written for the vapor composition of the component $i$, as follows:

$$
\sum_{i=1}^{n} y_{i}=\sum_{i=1}^{n} \gamma_{i} \mathrm{P}_{i}^{\circ} x_{i} / \pi=1
$$

The activity coefficients in Eq. (15) are predicted by using Eqs. (1) to (6).

The predicted results for the 25 isobaric vaporliquid equilibria of alcohol-water, alcohol-alcohol, alcohol-paraffin and alcohol-aromatic hydrocarbon systems are shown in Table 3 with the absolute arithmetic mean deviations between ex- perimental and predicted vapor compositions and temperature data. The deviations obtained from the parameters of Derr and Deal, and Tochigi and Kojima are also shown in Table 3 . The benzene molecule is treated as 6.0 interaction $\mathrm{CH}_{2}$

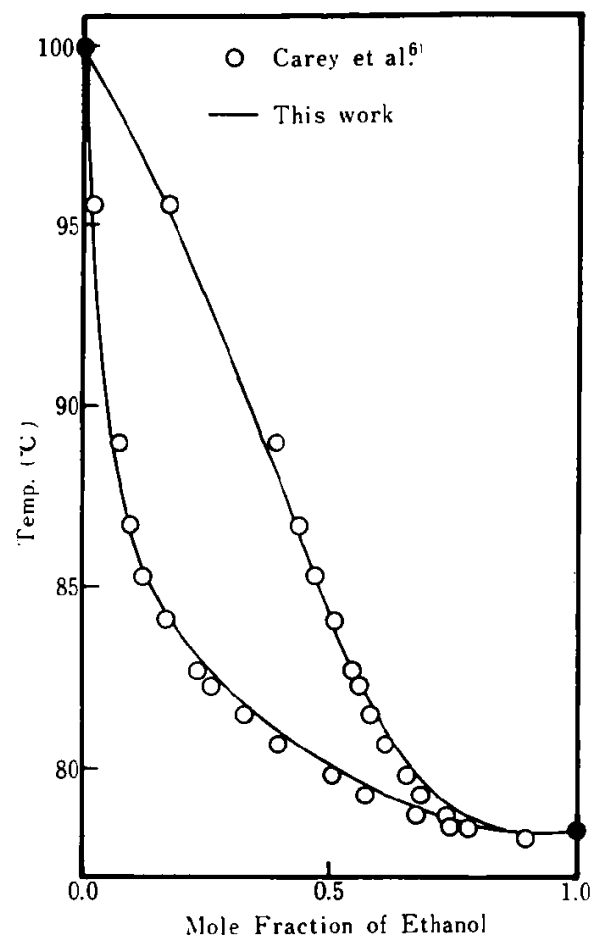

Fig. 1 Temperature-Composition Diagram for Ethanol (1)-Watcr (2) System at 760 $\mathrm{mmHg}$

Table 3 Deviations of Predicted Data from Experimental Vapor-Liquid Equilibrium

\begin{tabular}{|c|c|c|c|c|c|c|c|c|c|c|c|}
\hline \multirow{2}{*}{$\begin{array}{c}\text { System } \\
\text { Component (1)-Component (2) }\end{array}$} & \multirow{2}{*}{$\begin{array}{c}\text { Press. } \\
(\mathrm{mmHg})\end{array}$} & \multirow{2}{*}{$\begin{array}{c}\text { Temp. } \\
\text { Range } \\
\left({ }^{\circ} \mathrm{C}\right)\end{array}$} & \multicolumn{6}{|c|}{ Absolute Arithmetic Deviation } & \multirow[b]{2}{*}{$\mathrm{N}^{*}$} & \multirow[b]{2}{*}{ Ref. } & \multirow[b]{2}{*}{ Note } \\
\hline & & & $\begin{array}{l}\text { This } \\
\text { Work }\end{array}$ & $\begin{array}{l}1 \times 1,00 \\
\text { T.K* }\end{array}$ & D.D* & \begin{tabular}{|l} 
This \\
Work
\end{tabular} & $\mathrm{t}\left[{ }^{\circ} \mathrm{C}\right]$ & D. D. & & & \\
\hline $\begin{array}{l}\text { Methanol-Water } \\
\text { Ethanol-Water } \\
n \text {-Propanol-Water } \\
\text { Methanol-Ethanol } \\
\text { Methanol- } i \text {-Propanol } \\
\text { Ethanol- } i \text {-Propanol } \\
\text { Ethanol- } n \text {-Butanol } \\
i \text {-Propanol-n-Propanol } \\
\text { Methanol- } n \text {-Heptane } \\
\text { Ethanol- } n-\text { Hexane } \\
\text { Ethanol- } n \text {-Heptane } \\
n \text {-Propanol-n-Hexane } \\
n \text {-Propanol-n-Heptane } \\
n \text {-Butanol-n-Octane } \\
n \text {-Butanol-n-Nonane } \\
\text { Ethanol-Benzene } \\
n \text {-Propanol-Benzene }\end{array}$ & $\begin{array}{l}760 \\
760 \\
760 \\
760 \\
760 \\
760 \\
760 \\
760 \\
760 \\
760 \\
760 \\
760 \\
760 \\
760 \\
760 \\
760 \\
760\end{array}$ & \begin{tabular}{|c|}
$64.65-100.0$ \\
$78.15-100.0$ \\
$87.7-100.0$ \\
$64.65-78.3$ \\
$64.65-82.4$ \\
$78.3-82.4$ \\
$78.3-117.5$ \\
$82.4-97.2$ \\
$58.81-98.42$ \\
$58.4-78.32$ \\
$71.0-98.4$ \\
$65.7-97.2$ \\
$84.6-98.4$ \\
$108.5-125.7$ \\
$115.9-150.8$ \\
$67.9-80.1$ \\
$76.0-97.2$
\end{tabular} & $\begin{array}{l}5 \\
7 \\
25.7 \\
15 \\
15 \\
40.3 \\
12 \\
5.3 \\
9 \\
15 \\
34 \\
42.4 \\
17 \\
26 \\
7 \\
31 \\
54\end{array}$ & $\begin{array}{l}6 \\
7 \\
26.4 \\
15 \\
15 \\
40.3 \\
12 \\
5.3 \\
8 \\
16 \\
35 \\
42.5 \\
17 \\
27 \\
8 \\
31 \\
53\end{array}$ & $\begin{array}{l}13 \\
24 \\
50 \\
15 \\
\frac{-}{12} \\
\frac{12}{9} \\
14 \\
33 \\
44.0 \\
18 \\
33 \\
13 \\
36 \\
56\end{array}$ & $\begin{array}{l}0.4 \\
0.35 \\
1.11 \\
0.3 \\
0.9 \\
0.1 \\
0.2 \\
0.2 \\
0.48 \\
1.24 \\
2.0 \\
1.5 \\
0.9 \\
0.8 \\
0.4 \\
2.5 \\
1.7\end{array}$ & $\begin{array}{l}0.4 \\
0.39 \\
1.14 \\
0.3 \\
0.9 \\
0.1 \\
0.2 \\
0.2 \\
0.51 \\
1.26 \\
2.1 \\
1.5 \\
0.9 \\
0.9 \\
0.5 \\
2.5 \\
1.7\end{array}$ & $\begin{array}{l}1.0 \\
1.4 \\
2.32 \\
0.3 \\
- \\
0 . \overline{0.2} \\
\overline{0} \\
0.19 \\
0.80 \\
1.8 \\
1.6 \\
0.9 \\
1.5 \\
1.2 \\
2.8 \\
1.9\end{array}$ & $\begin{array}{r}15 \\
15 \\
19 \\
12 \\
8 \\
13 \\
9 \\
14 \\
7 \\
9 \\
18 \\
12 \\
9 \\
10 \\
9 \\
10 \\
12\end{array}$ & \begin{tabular}{|r|}
75 \\
65 \\
$16)$ \\
15 \\
35 \\
35 \\
$11)$ \\
35 \\
45 \\
175 \\
145 \\
235 \\
$10)$ \\
15() \\
155 \\
$21)$ \\
$23)$ \\
\end{tabular} & \\
\hline $\begin{array}{l}n \text {-Butanol- } n \text {-Heptane } \\
\text { Methanol-Water } \\
\text { Methanol-Water } \\
\text { Methanol-Water } \\
\text { Ethanol-Water } \\
\text { Ethanol-Water } \\
\text { Ethanol-Water } \\
\text { Ethanol-Water }\end{array}$ & $\begin{array}{r}1,445 \\
3,800 \\
6,080 \\
8,512 \\
2,586 \\
5,172 \\
10,344 \\
15,512\end{array}$ & $\begin{array}{l}114.8-137.0 \\
112.2-152.3 \\
129.1-169.5 \\
142.0-185.4 \\
112.6-134.6 \\
136.7-164.2 \\
164.2-194.1 \\
182.6-213.8\end{array}$ & $\begin{array}{c}25 \\
9.9 \\
11.5 \\
14.0 \\
9 \\
19 \\
30 \\
41\end{array}$ & $\begin{array}{l}26 \\
10.0 \\
11.7 \\
14.5 \\
10 \\
21 \\
32 \\
45\end{array}$ & $\begin{array}{l}33 \\
13.0 \\
14.6 \\
16.5 \\
8 \\
10 \\
17 \\
23\end{array}$ & $\begin{array}{l}1.1 \\
1.3 \\
1.2 \\
1.1 \\
0.3 \\
1.2 \\
2.2 \\
3.2\end{array}$ & $\begin{array}{l}1.2 \\
1.3 \\
1.1 \\
1.0 \\
0.3 \\
1.3 \\
2.5 \\
3.5\end{array}$ & $\begin{array}{l}2.2 \\
1.7 \\
1.7 \\
1.8 \\
0.9 \\
0.4 \\
0.7 \\
1.0\end{array}$ & $\begin{array}{l}10 \\
22 \\
22 \\
22 \\
18 \\
18 \\
18 \\
17\end{array}$ & $\begin{array}{l}30) \\
12) \\
12) \\
12) \\
22) \\
22) \\
22) \\
22)\end{array}$ & $\begin{array}{rr}5 & \text { atm } \\
8 & \text { atm } \\
11.2 \text { atm } \\
50 & \text { psia } \\
100 & \text { psia } \\
200 & \text { psia } \\
300 & \text { psia }\end{array}$ \\
\hline
\end{tabular}
Data for Binary Systems

${ }^{*} \mathrm{~T} . \mathrm{K}=$ by Tochigi and Kojima's parameters ${ }^{*} \mathrm{D}, \mathrm{D}=$ by Derr and Deal's parameters ${ }^{*} \mathrm{~N}=$ No. of data points 


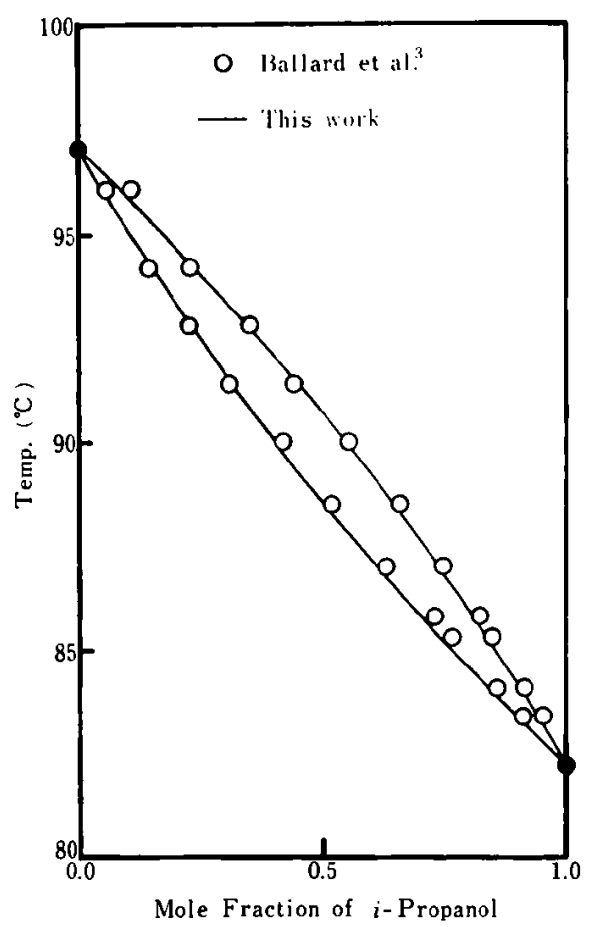

Fig. 2 Temperature-Composition Diagram for $i$-Propanol (1)-n-Propanol (2) System at 760 $\mathrm{mmHg}$

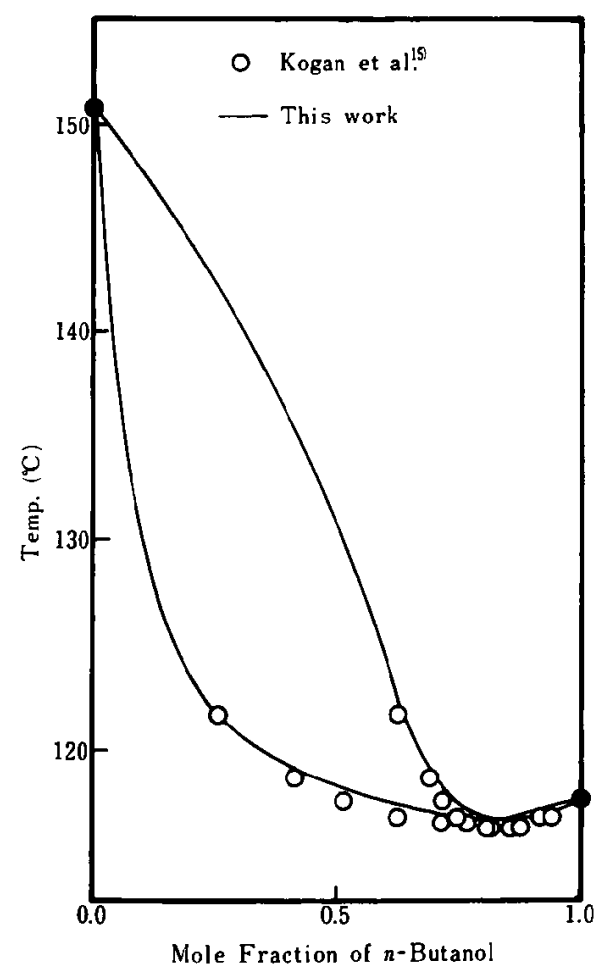

Fig. 3 Temperature-Composition Diagram for $n$ Butanol (1)-n-Nonane (2) System at 760 $\mathrm{mmHg}$

group.

Figs. 1 to 4 show the predicted vapor-liquid equilibria with the experimental temperature vs. liquid composition data for ethanol-water, $i$-pro-

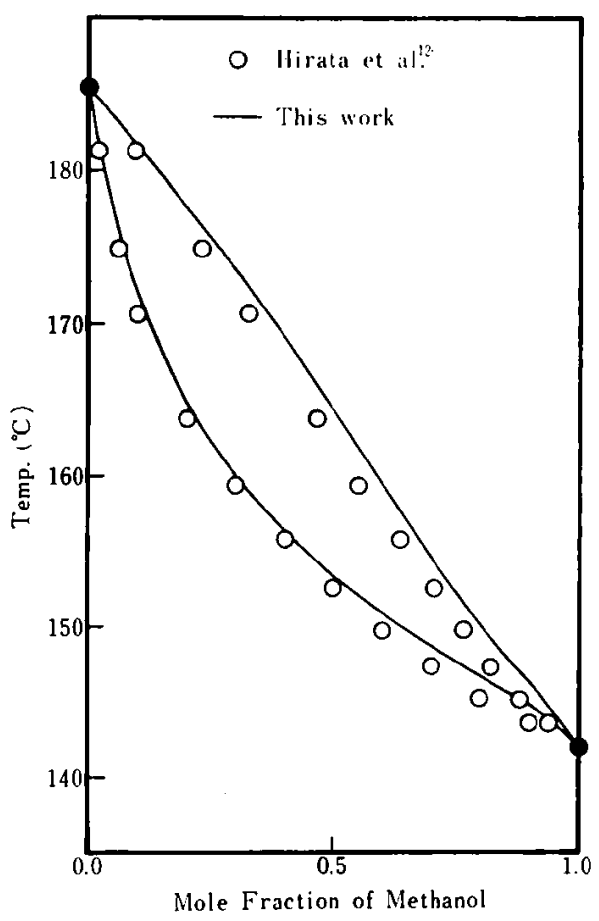

Fig. 4 Temperature-Composition Diagram for Methanol (1)-Water (2) System at $11.2 \mathrm{~atm}$

panol- $n$-propanol, $n$-butanol- $n$-nonane, and methanol-water systems, respectively.

The predicted results in Table 3 and Figs. 1 to 4 show good agreement with those of the experiments.

\section{Prediction of Solid-Liquid Equilibria}

Solid-liquid equilibria considered in this paper are those for which the solid phase is assumed to be the pure solute and the liquid phase is a saturated solution of the solute in the solvent. Thus, the liquid phase activity coefficients for the solute component $i$ of solid-liquid equilibria were calculated using the simple Van't Hoff isochore equation which is given by Eq. (16).

$$
\ln \gamma_{i} x_{i}=\frac{\Delta \mathrm{H}_{i}}{\mathrm{RT}}-\frac{\left(\mathrm{T}-\mathrm{T}_{i}^{\mathrm{M}}\right)}{\mathrm{T}_{i}^{\mathrm{M}}}
$$

where $\Delta \mathrm{H}_{i}$ is the heat of fusion of the solute component $i, \mathrm{R}$ is the gas constant and $\mathrm{T}_{i}^{\mathrm{M}}$ is the temperature of melting point of the solute component $i$. Eq. (16) can be written for liquid composition of the solute component $i$, as follows :

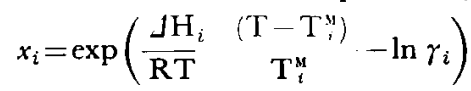

The activity coefficients in Eq. (17) are predicted by using Eqs. (1) to (6).

The predicted results for solid-liquid equilibria of naphthalene-alcohol systems are listed in Table 4 with the absolute arithmetic mean deviations 
Table 4 Deviations of Predicted Data from Experimental Solid-Liquid Equilibrium 1)ata for Binary Systems

\begin{tabular}{|c|c|c|c|c|}
\hline $\begin{array}{l}\text { System } \\
\text { Component (1)-Compo- } \\
\text { nent (2) }\end{array}$ & $\Delta x_{1}^{*}$ & $\begin{array}{c}\text { Temp. } \\
\text { Range } \\
\left({ }^{\circ} \mathrm{C}\right)\end{array}$ & $\mathrm{N}^{*}$ & Ref. \\
\hline $\begin{array}{l}\text { Naphthalene-Ethanol } \\
\text { Naphthalene- } n \text {-Propanol } \\
\text { Naphthalene- } i \text {-Propanol } \\
\text { Naphthalene- } n \text {-Butanol } \\
\text { Naphthalene- } i \text {-Butanol }\end{array}$ & $\begin{array}{l}55.3 \\
38.4 \\
45.3 \\
31.8 \\
30.1\end{array}$ & $\begin{array}{l}20.0-80.0 \\
20.0-80.0 \\
20.0-80.0 \\
25.0-80.0 \\
20.0-80.0\end{array}$ & $\begin{array}{l}11 \\
11 \\
11 \\
10 \\
11\end{array}$ & $\begin{array}{l}\text { 2) } \\
\text { 2) } \\
\text { 2) } \\
\text { 2) } \\
\text { 2) }\end{array}$ \\
\hline
\end{tabular}

$* j x_{1}=\left[\left|\left(x_{1, e x p}-x_{1, c a l}\right)\right| / N\right] \times 1,000$

$* \mathbf{N}=$ No. of data points

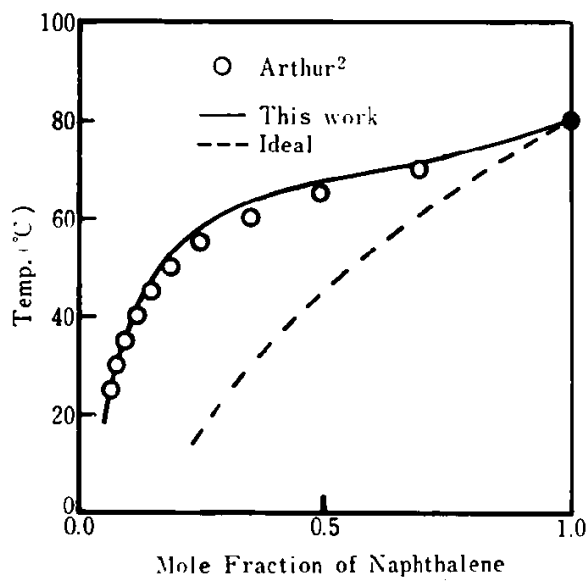

Fig. 5 Solubility Diagram of Solid Naphthalene in Liquid Phase for Naphthalene (1)-n-Butanol (2) System

between observed and predicted liquid compositions obtained by means of our parameters. Fig. 5 shows the predicted solid-liquid equilibria with the experimental temperature vs. liquid composition data for the naphthalene- $n$-butanol system. Assuming the systems ideal, i.e. $\gamma_{i}$ in Eqs. (16) and (17) are taken to be 1.0, the calculated values are also plotted in Fig. (5).

The predicted solid-liquid equilibrium data shown in Table 4 and Fig. 5 indicated good agreement with the experimental data.

In this study, the naphthalene molecule is treated as 10.0 interaction $\mathrm{CH}_{2}$ groups and the value of $\mathrm{CH}_{2}$ group in $i$-butanol is taken as 3.8 .

\section{Conclusions}

The group Wilson parameters to predict liquid phase activity coefficients by the ASOG model for the systems consisting of $\mathrm{CH}_{2}$ and $\mathrm{OH}$ groups were determined using the isothermal vapor-liquid equilibrium data of the alcohol-water and alcoholparaffin systems at temperatures 30, 50, 60 and $90^{\circ} \mathrm{C}$. The isobaric vapor-liquid equilibria of the binary systems involving alcohols, water, paraffins and benzene were successfully predicted even within the temperature range from $90^{\circ} \mathrm{C}$ to $215^{\circ} \mathrm{C}$ and the pressures up to $20 \mathrm{~atm}$. Also, the prediction of binary solid-liquid equilibria of the naphthalene-alcohol systems showed good agreement with those of the experimental data.

\section{Acknowledgment}

The authors express their thanks to Mr. Masaru Toyohara for his assistance in the computational work.

\section{Nomenclature}

$$
\begin{array}{rlrl}
\mathrm{a} & =\text { group Wilson parameter } & {[-]} \\
\Delta \mathrm{H} & =\text { heat of fusion } & & {[\mathrm{cal} / \mathrm{g}-\mathrm{mol}]} \\
\mathrm{P} & =\text { vapor pressure } & & {[\mathrm{mmHg}]} \\
\mathrm{R} & =\text { gas constant } & & {[\mathrm{cal} / \mathrm{g}-\mathrm{mol} \cdot \mathrm{k}]} \\
\mathrm{T} & =\text { absolute temperature } & & {[\mathrm{K}]} \\
\mathrm{U} & =\text { solute group ratio } & {[-]} \\
\mathrm{X} & =\text { group fraction } & {[-]} \\
x & =\text { mole fraction in liquid } & \\
& \text { phase } & {[-]} \\
y & =\text { mole fraction in vapor } & \\
& \text { phase } & {[-]} \\
\Gamma= & \text { group activity coefficient } & {[-]} \\
\gamma & =\text { activity coefficient } & {[-]} \\
\pi & =\text { total pressure } & {[\mathrm{mmHg}]} \\
\nu & =\text { number of groups } & {[-]}
\end{array}
$$

Subscripts

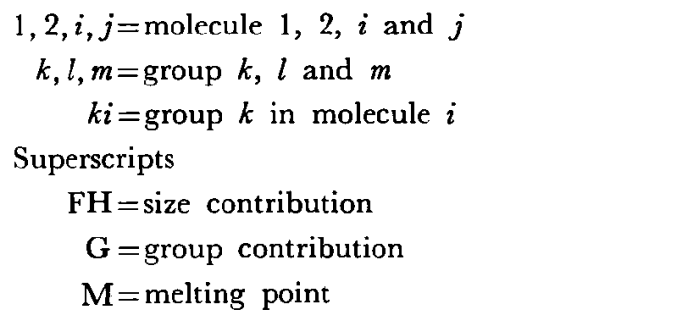

\section{Literature Cited}

1) Amer, H. H., Paxton, R. R., van Winkle, M., Ind. Eng. Chem., 48, 142 (1956).

2) Arthur, A. S., J. Phys. Chem., 34, 2582 (1930).

3) Ballard, L. H., van Winkle, M., Ind. Eng. Chem., 44, 2450 (1952).

4) Benedict, M., Johnson, A., Solomon, E., Rubin, L. G., Trans. Am. Inst. Chem. Eng., 41, 371 ' (1945).

5) Broul, M., Hlavaty, K., Linek, J., Collection Czech. Chem. Commun., 34, 3428 (1969).

6) Garey, J. S., Lewis, W. K., Ind. Eng. Chem., 24, 882 (1932).

7) Ghu, Ju Ghin, Getty, R. J., Brennecke, L. F., Paul, R., Distillation Equilibrium Data, Reinhold, (1950).

8) Derr, E. L., Deal, G. H., I. Chem. E. Symposium Series, 32, P. 3: 40 (1969).

9) Dulitskaya K. A., Zh. Obshch. Khim., 15, 9 (1945).

10) Gurukul, S. M. K. A., Raju, B. N., J. Chem. Eng. 
Data, 11, 501 (1966).

11) Hellwig, L. R., van Winkle, M., Ind. Eng. Chem., 45, 62+ (1953).

12) Hirata M., Suda, S., Kagaku Kogaku, 31, 759 (1967).

13) Ishii, N., Kogyo Kagaku Zasshi, 38, 659 (1935).

14) Katz, K., Newman, M., Ind. Eng. Chem., 48, 137 (1956).

15) Kogan, V. B., Fridman, V. M., Romanovai, T. G., Zh. Fiz. Khim., 29, 685 (1955).

16) Kojima, K., Kato, M., Sunaga, H., Hashimoto, S., Kagaku Kogaku, 32, 337 (1968).

17) Kudryavtseva, L. S., Susarev, M. P., Zh. Prikl. Khim., 36, 1231 (1963).

18) Maripuri, V. C., Ratcliff, G. A., Canadian J. Chem. Eng., 49, 506 (1971).

19) Mcglashan, M. L., Williamson, A. G., J. Chem. Eng. Data, 21, 196 (1976).

20) Murti, P. S., van Winkle, M., Chem. Eng. Data Series, 3, 72 (1958).

21) Niini, A., Ann. Acrd. Sci. Fenn., A 55, No. 8 (1940).
22) Otsuki, H., Williams, F. C., Chem. Eng. Prog. Symp. .jeries, 49, (6), 55 (1953).

23) Parabhu, P. S., van Winkle, M., J. Chem. Eng. Data, 8, 210 (1963).

24) Ratcliff, G. A., Chao, K. C., Canadian J. Chem. Eng., 47, 148 (1969).

25) Ronc, M., Ratcliff, G. A., ibid., 49, 825 (1971).

26) Smith, G. P., Engel, E. W., J. Am. Chem. Soc., 51, 2660 (1929).

27) Tochigi, K., Kojima, K., J. Chem. Eng. Japan, 9, (4), 267 (1976).

28) Udovenko, V. V., Fatkulina, L. G., Zh. Fiz. Khim., 26, 1438 (1952).

29) van Ness, H. C., Soczek, C. A., Peloquin, G. L., Machado, R. L., J. Chem. Eng. Data, 12, 217 (1967).

30) Vijayaraghavan, S. V., Deshpande, P. K., Kuloor, N. R., ibid., 12, 15 (1967).

31) Wilson, G. M., Deal, C. H., Ind. Eng. Chem. Fundamentals, 1, 20 (1962).

32) Wrewsky, M. S., Z. Phys. Chem., 81, 1 (1912). 